\title{
Specific and Sensitive Primers Developed by Comparative Genomics to Detect Bacterial Pathogens in Grains
}

\author{
Kwang Yeol Baek ${ }^{1 \dagger}$, Hyun-Hee Lee ${ }^{2 \dagger}$, Geun Ju Son ${ }^{1 \dagger}$, Pyeong An Lee ${ }^{1 \dagger}$, Nazish Roy ${ }^{1}$, Young-Su Seo ${ }^{2 *}$, and \\ Seon-Woo Lee ${ }^{1 *}$ \\ ${ }^{1}$ Department of Applied Bioscience, Dong-A University, Busan 49315, Korea \\ ${ }^{2}$ Department of Microbiology, Pusan National University, Busan 46241, Korea
}

(Received on November 24, 2017; Revised on January 11, 2018; Accepted on January 11, 2018)

Accurate and rapid detection of bacterial plant pathogen is the first step toward disease management and prevention of pathogen spread. Bacterial plant pathogens Clavibacter michiganensis subsp. nebraskensis (Cmn), Pantoea stewartii subsp. stewartii (Pss), and Rathayibacter tritici (Rt) cause Goss's bacterial wilt and blight of maize, Stewart's wilt of maize and spike blight of wheat and barley, respectively. The bacterial diseases are not globally distributed and not present in Korea. This study adopted comparative genomics approach and aimed to develop specific primer pairs to detect these three bacterial pathogens. Genome comparison among target pathogens and their closely related bacterial species generated 15-20 candidate primer pairs per bacterial pathogen. The primer pairs were assessed by a conventional PCR for specificity against 33 species of Clavibacter, Pantoea, Rathayibacter, Pectobacterium, Curtobacterium. The investigation for specificity and sensitivity of the primer pairs allowed final selection of one or two primer pairs per bacterial pathogens. In our assay condition, a detection limit of $P$ ss and $C m n$ was $2 \mathrm{pg} / \mu \mathrm{l}$ of genomic DNA per PCR reaction, while the

\footnotetext{
${ }^{\dagger}$ These authors contributed equally to this work as first authors.

*Co-corresponding authors.

Young-Su Seo

Phone) +82-51-510-2267, FAX) +82-51-514-1778

E-mail)yseo2011@pusan.ac.kr

Seon-Woo Lee

Phone) +82-51-200-7551, FAX) +82-51-200-7505

E-mail)seonlee@dau.ac.kr

(c) This is an Open Access article distributed under the terms of the Creative Commons Attribution Non-Commercial License (http:// creativecommons.org/licenses/by-nc/4.0) which permits unrestricted noncommercial use, distribution, and reproduction in any medium, provided the original work is properly cited.
}

Articles can be freely viewed online at www.ppjonline.org. detection limit for $R t$ primers was higher. The selected primers could also detect bacterial cells up to $8.8 \times 10^{3}$ cfu to $7.84 \times 10^{4}$ cfu per gram of grain seeds artificially infected with corresponding bacterial pathogens. The primer pairs and PCR assay developed in this study provide an accurate and rapid detection method for three bacterial pathogens of grains, which can be used to investigate bacteria contamination in grain seeds and to ultimately prevent pathogen dissemination over countries.

Keywords: Clavibacter michiganensis subsp. nebraskensis, comparative genomics, Pantoea stewartii subsp. stewartii, PCR detection, Rathayibacter tritici

Handling Associate Editor : Oh, Chang-Sik

The economic impact of plant diseases caused by bacterial pathogens escalates with global warming (Castillo and Plata, 2016) with an increase in international exchange of grains and vegetables among countries (Nutter and Madden, 2009). Comparatively, a number of bacterial pathogens prefer higher temperatures, for infection, than the fungal pathogens. The magnitude of risk for bacterial pathogens dissemination is directly proportional to the massive global exchange of the agricultural products (Pautasso et al., 2010). Therefore, precise measures for plant quarantine become important to restrict dissemination of bacterial plant pathogen globally to ensure secure agricultural production.

Bacterial pathogens, Clavibacter michiganensis subsp. nebraskensis (Cmn), Pantoea stewartii subsp. stewartii (Pss), Rathayibacter tritici (Rt, formerly Clavibacter tritici), are not globally distributed and are thus quarantined pathogens in many countries including Korea. Cmn is a 
Gram-positive bacterial pathogen causing Goss's bacterial wilt and blight of maize (Zea mays L.) (Vidaver and Mandel, 1974). The disease shows two different symptoms: a leaf blight and a systematic vascular wilt (Agarkova et al., 2011). Since the first report of this disease in 1969 in the USA, this disease is only limited in USA and Canada (Agarkova et al., 2011; Eggenberger et al., 2016; Vidaver and Mandel, 1974). Transmission of this disease is either through infected seeds or bacteria-infested residues. Rate of transmission via seeds is lower than bacteria-infested residues which seem to be the primary source of inoculum in disease spread (Smidt and Vidaver, 1986). Diagnosis and detection of Goss's wilt and bacterial pathogen are currently dependent on disease symptoms, immunological assays and selective medium for bacterial pathogen.

PSS causes Stewart's wilt of maize, mostly transmitted by the corn flea beetle (Chaetoconema pulicaria) and infected seeds (Michener et al., 2002) and the disease is under plant quarantine regulations in more than 60 countries on maize seeds imports from affected areas (Pataky and Ikin, 2003). Symptoms of Stewart's wilt are somewhat similar to Goss's wilt by Cmn and thus a careful examination is necessary to distinguish the two diseases. To differentiate plant-associated Pantoea species, several methods have been developed. Immunoassay or polymerase chain reaction (PCR) primers have been described (Coplin et al., 2002; Lamka et al., 1991; Tambong et al., 2008; Wensing et al., 2010). However, those analyses cannot completely distinguish species of Pantoea or subspecies of P. stewartii (Wensing et al., 2014). Recently, Wensing et al. (2014) developed a single-nucleotide polymorphism based PCR assay to differentiate PSS from $P$. stewartii subsp. indologenes.

$R t$ is a Gram-positive coryneform bacterial pathogen causing spike blight, also called yellow ear rot or Tundu disease, in wheat and barley (Paruthi and Gupta, 1987). Rt infection and rapid spread is frequently associated with $\mathrm{An}$ guina tritici, a nematode, producing seed galls (ear cockles) in certain plant varieties (Paruthi and Bhatti, 1985). Despite the wide distribution of this bacterial pathogen (Park et al., 2017), no reliable detection method has been reported so far.

DNA-based diagnostic methods such as PCR have been widely used as an effective approach to detect bacterial pathogens from diseased plants, which offer advantages over traditional antibody-based detections which are expensive and time consuming processes (Cho et al., 2011; De Boer et al., 1988; Gudmestad et al., 2009; Vincelli and Tisserat, 2008). Either the 16S rRNA gene or the spacer region between the $16 \mathrm{~S}$ and $23 \mathrm{~S}$ rRNA genes of bacterial pathogen, known phylogenetic markers, have been primarily targeted for amplification by PCR (Kang et al., 2016). The possibility for use of these sequences to detect bacterial pathogens remains technically limited to sensitively distinguish bacteria at species or below species level (Baker et al., 2003; Henriques et al., 2012). Hence, there are growing efforts to search for new marker gene or sequences to be developed as detection markers for bacterial pathogens of plants with high reliability. A perpetual increase in the availability of whole genome sequences of bacterial pathogens has shifted the attention to use of comparative genome analysis, which is the most effective ways to select candidate marker gene of bacterial pathogens (Ahmed et al., 2008; Demkin et al., 2017; Papaiakovou et al., 2017; Tao et al., 2015).

Since there are no primers available to detect bacterial pathogens, $C m n$ and $R t$, we aimed to develop specific and sensitive primers to detect bacterial pathogens in grains. In this study, by taking advantage of comparative genome analysis of bacterial pathogens, we assessed several candidate primers to detect three bacterial pathogens of grains, and selected the specific and sensitive primer pairs for these bacterial pathogens.

\section{Materials and Methods}

Bacterial strains and culture condition. Most of bacterial strains used in this study were obtained from the National Collection of Plant Pathogenic Bacteria (NCPPB, York, UK) and the Korean Agricultural Culture Collection (KACC, Korea) (Table 1). Bacterial strains of C. michiganensis subsp. capsici ( $\mathrm{Cmc}$ ) (Oh et al., 2016) and $\mathrm{Cmm}$ (Yim et al., 2012) were kindly provided from Chang-Sik $\mathrm{Oh}$ at the Kyung Hee University, and Jae-Soon Cha at the Chungbuk National University, Korea, respectively. All of bacterial strains from NCPPB are listed as plant quarantine bacteria in Korea and many other countries, therefore, these strains were obtained under official permission from Animal and Plant Quarantine Agency, Korea for use only in a restricted area during limited time period.

Both Clavibacter species and Pectobacterium species were grown at $25^{\circ} \mathrm{C}$ while Pantoea species were grown at $30^{\circ} \mathrm{C}$ in nutrient broth (NB). The Rathayibacter species were grown in nutrient broth yeast extract broth (NBY) (Hayward, 1964) at $25^{\circ} \mathrm{C}$. Curtobacterium flaccumfaciens pv. flaccumfaciens (Cff) was grown in yeast peptone glucose agar medium (Vidaver, 1967) at $30^{\circ} \mathrm{C}$. Genomic DNA of bacterial strains was purified using a Wizard Genomic DNA Purification kit (Promega, Fitchburg, WI, USA) and the concentration of purified DNA was determined by us- 
Table 1. List of bacterial strains used in this study

\begin{tabular}{|c|c|c|c|}
\hline Strain $^{a}$ & & Host plant & Origin $^{b}$ \\
\hline \multicolumn{4}{|l|}{ Clavibacter } \\
\hline michiganensis subsp. capsici & PF008 (type) & Capsicum anпuиm & Korea \\
\hline michiganensis subsp. capsici & PF003 & Capsicum annuum & Korea \\
\hline michiganensis subsp. capsici & PF005 & Capsicum annuum & Korea \\
\hline michiganensis subsp. capsici & PS006 & Capsicum annuum (seed) & China* \\
\hline michiganensis subsp. michiganensis & LMG 7333 (type) & Solanum lycopersicum & Hungary \\
\hline michiganensis subsp. michiganensis & PPP1 & Solanum lycopersicum & Korea \\
\hline michiganensis subsp. nebraskensis & NCPPB 2581 (type) & Zea mays & USA \\
\hline michiganensis subsp. nebraskensis & NCPPB 2582 & Zea mays (seed) & USA \\
\hline michiganensis subsp. insidiosus & NCPPB 1109 (type) & Medicago sativa & USA \\
\hline michiganensis subsp. tesselarius & NCPPB 3664 (type) & Triticum aestivum & USA \\
\hline \multicolumn{4}{|l|}{ Curtobacterium } \\
\hline flaccumfaciens pv. flaccumfaciens & NCPPB 1446 (type) & Phaseolus vulgaris & Hungry \\
\hline flaccumfaciens pv. flaccumfaciens & NCPPB 2344 & Phaseolus vulgaris & USA \\
\hline \multicolumn{4}{|l|}{ Pantoea } \\
\hline agglomerans & KACC 10054 & Wisteria floribnda & Japan \\
\hline agglomerans & KACC 15275 (type) & Homo sapiens & Scotland \\
\hline ananatis pv. ananatis & NCPPB 3619 & Ananas comosus & Tailand \\
\hline stewartii subsp indologens & NCPPB 2280 (type) & Setaria italica & India \\
\hline stewartii subsp indologens & NCPPB 2282 & Pennisetum glaucum & India \\
\hline stewartii subsp stewartii & NCPPB 2295 (type) & Zea mays & USA \\
\hline stewartii subsp stewartii & NCPPB 3379 & Zea mays & USA \\
\hline stewartii subsp stewartii & NCPPB 1553 & Zea mays & USA \\
\hline stewartii subsp stewartii & NCPPB 3253 & Zea mays & Italy \\
\hline \multicolumn{4}{|l|}{ Pectobacterium } \\
\hline carotovorum subsp. carotovorum & KACC 10057 (type) & Solanum tuberosum & Denmark \\
\hline carotovorum subsp. carotovorum & KACC 10225 & Brassica rapa & Korea \\
\hline carotovorum subsp. carotovorum & KACC 10408 & Nicotiana tabacum & Korea \\
\hline carotovorum subsp. carotovorum & KACC 10421 & Raphanus sativus & Korea \\
\hline carotovorum subsp. carotovorum & KACC 10458 & Brassica rapa & Korea \\
\hline \multicolumn{4}{|l|}{ Rathayibacter } \\
\hline iranicus & NCPPB 2253 (type) & Triticum aestivum & Iran \\
\hline rathayi & NCPPB 2980 (type) & Dactylis glomerata & New Zealand \\
\hline tritici & NCPPB 1857 (type) & Triticum aestivum & Egypt \\
\hline tritici & NCPPB 1953 & Triticum aestivum & Iran \\
\hline tritici & NCPPB 255 & Triticum aestivum & Egypt \\
\hline tritici & NCPPB 471 & Triticum aestivum & India \\
\hline toxicus & NCPPB 3552 (type) & Lolium rigidum & Australia \\
\hline
\end{tabular}

${ }^{a}$ The (type) indicates type strain of the species or subspecies. ${ }^{\text {b }}$ This strain with * was isolated from seeds imported from China.

ing a NanoDrop2000 spectrophotometer (Thermo Scientific, Wilmington, DE, USA).

Primer design by comparative genomic analysis. To search for pathogen-specific genes of target bacterial pathogens, whole genome information of target bacteria and their closely related species was retrieved from National Center for Biotechnology Information (NCBI) database (ftp://ftp.ncbi.nlm.nih.gov/genomes/bacteria/) at completed or scaffold level of assembly except for contig level and is listed in Table 2. We also used whole genome sequence information of Rt previously studied (Park et al., 2017). Based on the acquired genomic information, BLASTN searches were initially performed using 2,801 coding sequences (CDS) of Cmn, 4,942 CDS of PSs and $2,995 \mathrm{CDS}$ of $R t$ as query against the constructed subject 
Table 2. Genome sequences of bacterial strains used in this study

\begin{tabular}{|c|c|c|c|c|c|}
\hline Strain & & Accession & $\begin{array}{l}\text { Size } \\
(\mathrm{Mb})\end{array}$ & $\begin{array}{c}\text { Assembly } \\
\text { level }\end{array}$ & $\begin{array}{l}\text { Release } \\
\text { date }\end{array}$ \\
\hline \multicolumn{6}{|l|}{ Clavibacter } \\
\hline michiganensis subsp. sepedonicus & ATCC 33113 & $\begin{array}{l}\text { NC_010407.1 } \\
\text { NC_010399.1 } \\
\text { NC_010408.1 }\end{array}$ & 3.40 & Completed & $2008 / 02 / 12$ \\
\hline michiganensis subsp. michiganensis & NCPPB 382 & NC_009478.1-NC_009480.1 & 3.40 & Completed & $2007 / 05 / 18$ \\
\hline michiganensis subsp. nebraskensis & NCPPB 2581 & NC_020891.1 & 3.06 & Completed & 2013/04/01 \\
\hline michiganensis subsp. insidiosus & R1-1 & NZ_CP011043.1-NZ_CP011046.1 & 3.41 & Completed & $2015 / 03 / 20$ \\
\hline michiganensis subsp. capsici & PF008 & NZ_CP011043.1-NZ_CP011046.1 & 3.24 & Completed & $2015 / 09 / 08$ \\
\hline \multicolumn{6}{|l|}{ Pantoea } \\
\hline stewartii subsp. stewartii & DC283 & NZ_CP017581.1-NZ_CP017592.1 & 5.31 & Completed & $2017 / 04 / 10$ \\
\hline stewartii subsp. indologenes & LMG 2632 & JPKO01000001-JPKO01000035 & 4.68 & Scaffolds & $2014 / 09 / 23$ \\
\hline stewartii & S301 & $\begin{array}{l}\text { NZ_LIIU01000001-NZ_ } \\
\text { LIIU01000027 }\end{array}$ & 4.49 & Scaffolds & $2015 / 10 / 13$ \\
\hline \multicolumn{6}{|l|}{ Rathayibacter } \\
\hline sp. & Leaf296 & $\begin{array}{l}\text { NZ_LMNR01000001-NZ_ } \\
\text { LMNR01000004 }\end{array}$ & 4.02 & Scaffolds & $2015 / 11 / 02$ \\
\hline tritici & NCPPB 1953 & NZ_CP015515.1 & 3.35 & Completed & 2016/05/09 \\
\hline toxicus & WAC3373 & NZ_CP013292.1 & 2.35 & Completed & $2015 / 12 / 14$ \\
\hline toxicus & 70137 & NZ_CP010848.1 & 2.33 & Completed & $2015 / 02 / 13$ \\
\hline
\end{tabular}

nucleotide sequences consisting of CDS of closely related species to the target bacterial pathogen. To eliminate genes highly matched to non-target bacteria, CDS with the lowest $e$-value $<0.1$ were discarded, the filtered CDS were reran and searched against the NCBI's non-redundant (nr) DNA sequence database ( $\mathrm{Yu}$ et al., 2010). The genes including non-matched $\mathrm{CDS}$ with $e$-value $\geq 0.05$, query coverage and identity $<30 \%$ were selected as candidates of the target bacterial pathogen-specific genes.

To find a region to be amplified by PCR experiments, the specific genes more than 500 bp were compared individually to the nr database in the NCBI BLAST web site (https:// blast.ncbi.nlm.nih.gov/Blast.cgi). Subsequently, primers were designed from the unmatched region using Primer3 program (Rozen and Skaletsky, 2000). Finally, specificity of the designed candidate primer pairs were predicted in silico by searching against the $\mathrm{nr}$ sequences via PrimerBLAST tool (https://www.ncbi.nlm.nih.gov/tools/primerblast) of NCBI with default option.

Polymerase chain reaction (PCR) and quantitative PCR (qPCR). Primer pairs used for PCR and qPCR amplification reactions are listed in Supplementary Table 1. Thermal cycling for PCR was performed according to the following program: an initial denaturation for $5 \mathrm{~min}$ at $95^{\circ} \mathrm{C}$, followed by 30 cycles of denaturation at $95^{\circ} \mathrm{C}$ for $30 \mathrm{~s}$, annealing at the specified temperature (Supplementary Table 1) for $30 \mathrm{~s}$, and a final extension at $72^{\circ} \mathrm{C}$ for $1 \mathrm{~min}$. PCR reaction mixture included all required components in a $50 \mu \mathrm{l}$ of reaction volume with $150 \mathrm{ng}$ of template genomic DNA. Negative control included PCR reaction without template DNA. When necessary for PCR sensitivity assay, template genomic DNA was serially diluted from $150 \mathrm{ng}$ to $0.1 \mathrm{ng}$.

qPCR was performed with reaction mixture containing SYBR Green Supermix (Bio-Rad, Hercules, CA, USA) and various concentrations of template genomic DNA at the following program: an initial denaturation for $2 \mathrm{~min}$ at $95^{\circ} \mathrm{C}$, followed by 39 cycles of denaturation at $95^{\circ} \mathrm{C}$ for 5 $\mathrm{s}$, annealing at the specified temperature (Supplementary Table 1) for $20 \mathrm{~s}$, and a final extension at $72^{\circ} \mathrm{C}$ for $30 \mathrm{~min}$. The qPCR data were displayed using the CFX Manager Software ver. 3.1. Each reaction was performed in triplicate. qPCR result of individual gene was evaluated using the iCycler iQ Real-Time PCR Detection System. The $C_{t}$ values of $\mathrm{qPCR}$ products of each gene were used to generate a standard curve against the number of gene copy (equivalent to the number of bacteria) used for qPCR (Supplementary Fig. 1-3). The number of gene (or genome) copy was obtained by dividing the amount of used DNA for qPCR (weight) with a molar weight of genomic DNA (genome size $(\mathrm{bp}) \times 660 \mathrm{~g} / \mathrm{bp}$ ), and multiplying by $6.02 \times$ $10^{23}$ molecules. 
PCR detection of bacteria on seeds. To detect bacterial pathogen from seeds, we followed a previously described method with slight modification (An et al., 2015). Clean corn seeds and dehulled wheat seeds were purchased and used to detect bacterial pathogens in the seeds by PCR. The seeds were surface sterilized by immersing in $70 \%$ ethanol for $30 \mathrm{~min}$ and subsequently in $1 \%$ sodium hypochlorite solution for $10 \mathrm{~min}$. Finally, the sterilized seeds were extensively washed 5 times with sterile distilled water, completely dried under a clean bench, and stored at $4^{\circ} \mathrm{C}$ until use. To artificially inoculate bacterial pathogens Cmn, Pss, $R t, 20$ gram of surface sterilized corn seeds and 10 gram of wheat seeds were incubated by shaking at $100 \mathrm{rpm}$ in a bacterial culture suspension ( 3 fold volume of seed volume with $10^{8} \mathrm{cfu} / \mathrm{ml}$ ) for $1 \mathrm{~h}$. The seeds were harvested by removing the bacterial suspension and dried under clean bench prior to storage at $4^{\circ} \mathrm{C}$. The surface sterilized seeds were used as negative controls.

To detect bacterial pathogens from the seeds, 10 gram of seeds was shaken at $180 \mathrm{rpm}$ for $5 \mathrm{~min}$ in sterile distilled water containing a drop of Tween 20 . The suspension was collected to determine the number of inoculated bacteria per seeds. Finally, the suspension was boiled at $95^{\circ} \mathrm{C}$ for 10 min, prior to PCR amplification to detect the presence of bacterial pathogen in the seeds.

\section{Results and Discussion}

Candidate primers generated by comparative genomics and specific detection of bacterial pathogens. Using comparative genomics among phylogenetically related bacterial pathogens, Cmn, Pss and Rt, we generated 1520 candidate primer pairs per bacterial pathogen to detect the corresponding bacterial pathogens (data not shown). Our first round of screening yielded the specific amplification of expected PCR products from the target bacterial pathogens (data not shown). All of the primer pairs which showed specific detection among the tested primers are listed in Table S1. Based on specificity and sensitivity, we further selected 2 primer pairs for each bacterial pathogen, namely: Cmn-3 (Fig. 1A) and Cmn-4 (Fig. 1B) for Cmn; Pss2-4 (Fig. 2A) and Pss2-9 (Fig. 2B) for Pss; Rt-4 (Fig. 3A) and Rt-5 (Fig. 3B) for Rt.

Since $R t$ was previously classified as a species of Clavibacter and separated from Clavibacter (Zgurskaya et al., 1993), we tested the primer pairs with Clavibacter species. Most of primer pairs designed by Rt genome information (Park et al., 2017) seem specific and neither detect the Clavibacter species nor the closely related Rathayibacter species such as $R$. toxicus, $R$. iranicus and $R$. rathayi (Fig. 3). PSs and many Pantoea species previously belonged to Erwinia species and were closely related to Erwinia species (Mergaert et al., 1993), which include Pectobacterium carotovorum (previously E. carotovora). Therefore, we tested Pss primer pairs with Pantoea species and P. carotovorum strains. PCR with Pss2-4 and Pss2-9 primer pairs resulted in the specific amplification from Pss strains which differed from other Pantoea species and P. carotovorum strains (Fig. 2).

Most of the primer pairs targeted amplification of genes encoding hypothetical proteins except Pss2-4, which amplified the gene encoding antiterminator $\mathrm{Q}$ of prophage of

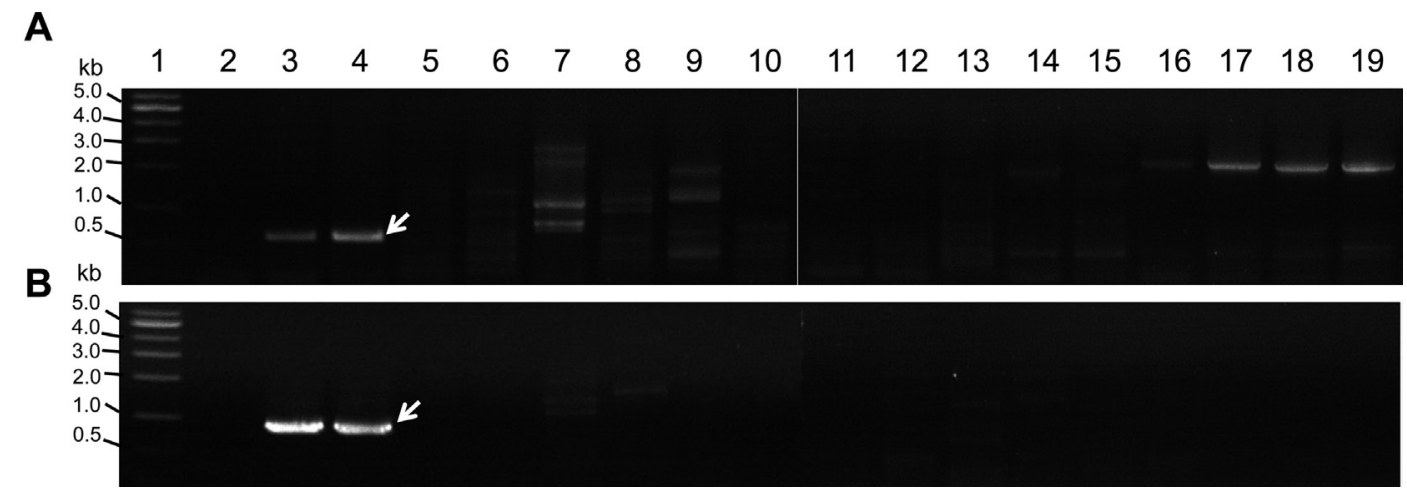

Fig. 1. Amplification of expected PCR product from Clavibacter michiganensis subsp. nebraskensis (Cmn) using two primer pairs. (A) Amplification by Cmn-3, (B) amplification by Cmn-4. Lane 1, DNA size standard (1 kb ladder); lane 2, no template DNA; lane 3, Cmn NCPPB 2581; lane 4, Cmn NCPPB 2582; lane 5, Rathayibacter tritici (Rt) NCPPB 255; lane 6, Rt NCPPB 471; lane 7, R. toxicus NCPPB 3552; lane 8, R. rathayi NCPPB 2980; lane 9, R. iranicus NCPPB 2253; lane10, C. michiganensis subsp. insidiosus NCPPB 1109; lane 11, C. michiganensis subsp. tesselarius NCPPB 3664; lane 12, Rt NCPPB 1857; lane 13, Rt NCPPB 1953; lane 14, C. michiganensis subsp. michiganensis (Cmm) NCPPB LMG7333; lane 15, Cmm PPP1; lane 16, C. michiganensis subsp. capsici (Cmc) PF003; lane 17, Cmc PF005; lane 18, Cmc PS006; lane 19, Cmc PF008. The white arrow represents the expected PCR product. 
A

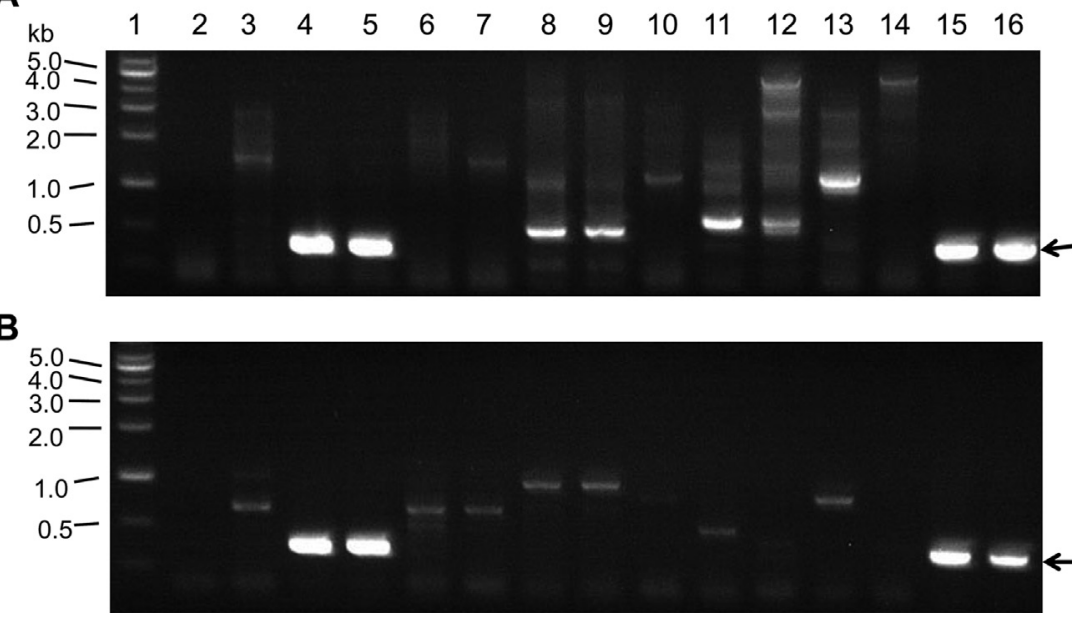

Fig. 2. Specific detection of Pantoea stewartii subsp. stewartii (Pss) using two primer pairs. (A) Amplification by Pss2-4, (B) amplification by Pss29. Lane 1, DNA size standard (1 kb ladder); lane 2, no template DNA; lane3, $P$. stewartii subsp. indologens (Psi) NCPPB 2280; lane 4, Pss NCPPG 1553; lane 5, Pss NCPPB 3253; lane 6, P. ananatis pv. ananatis (Paa) NCPPB 3619; lane 7, Psi NCPPB 228; lane 8, P. agglomerans (Pa) NCPPB 10054; lane 9, $\mathrm{Pa}$ NCPPB 15275; lane 10, Pectobacterium carotovorum subsp. carotovorum (Pcc) KACC 10057; lane 11, Pcc KACC 10225; lane 12, Pcc KACC 10408; lane 13, Pcc KACC 10421; lane 14, Pcc KACC 10458; lane 15, Pss NCPPB 2295; lane 16, Pss NCPPB 3379. The arrow on the right represents the expected PCR product.
Pss. In case of the gene for antiterminator $\mathrm{Q}$, it could be strain-specific and may not be considered suitable for specific detection. However, all of the 4 strains tested for Pss exhibited the specific amplification of the gene (Fig. 2A), suggesting that the gene encoding antiterminator $\mathrm{Q}$ would be a good marker for PSS detection. Other primer pairs which targeted the gene encoding hypothetical proteins should be carefully evaluated with more target bacterial strains. Genes encoding bacterial virulence determinants, such as toxins and plant cell wall degrading enzymes (CWDE), could serve as bacteria specific targets for detection. However, our preliminary comparative genome analysis indicated that genes for the virulence factors are not bacterial species or subspecies-specific, which can mislead for detection of bacterial pathogens from grains. In fact, it was previously reported that several bacterial genes encoding toxins or CWDE are conserved among different bacterial species (Lee et al., 2016; Murray et al., 2017).

Sensitivity of the selected primers. While most of candidate primer pairs amplified the expected PCR products from target pathogens but not from other related bacterial strains, the sensitivity seemed to be variable from each primer pair against the target pathogens. Therefore, we tested sensitivity of the primer pairs using serially diluted templated DNA from the type strain of three bacterial pathogens Cmn, Pss, Rt, and an additional strain in the same species for Cmn and Rt. At the indicated PCR condition, primers Cmn-3 and Cmn-4 to detect Cmn (Fig. 4A), Pss2-4 and Pss2-9 to detect Pss (Fig. 4B), were highly sensitive to

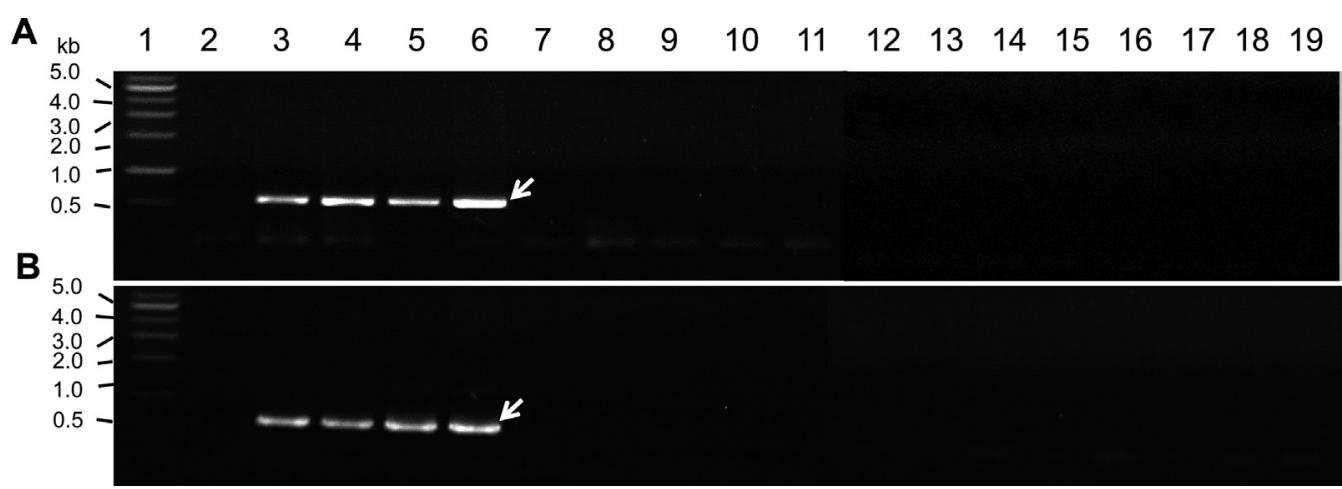

Fig. 3. Specific amplification of PCR product from Rathayibacter tritici $(R t)$ using selected two primer pairs. (A) Amplification by Rt4, (B) amplification by Rt-5. Lane 1, DNA size standard (1 kb ladder); lane 2, no template DNA; lane 3, Rt NCPPB 1857; lane 4, Rt NCPPB 1953; lane 5, Rt NCPPB 255; lane 6, Rt NCPPB 471; lane 7, C. michiganensis subsp. nebraskensis (Cmn) NCPPB 2581; lane 8, Cmn NCPPB 2582; lane 9, $R$. toxicus NCPPB 3552; lane 10, $R$. rathayi NCPPB 2980; lane 11, $R$. iranicus NCPPB 2253; lane 12, $C$. michiganensis subsp. insidiosus NCPPB 1109; lane 13, C. michiganensis subsp. tesselarius NCPPB 3664; lane 14, C. michiganensis subsp. michiganensis (Cmm) LMG 7333; lane 15, Cmm PPP1; lane 16, C. michiganensis subsp. capsici (Cmc) PF003; lane 17, Cmc PF005; lane 18, Cmc PS006; lane 19, Cmc PF008. The white arrow represents the expected PCR product. 
A

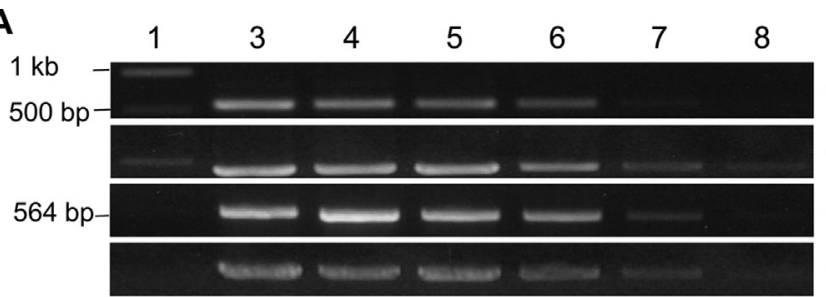

\begin{tabular}{l|l} 
Primer & Strain \\
Cmn-3 & Cmn NCPPB 2581 \\
Cmn-4 & \\
Cmn-3 & Cmn NCPPB 2582 \\
Cmn-4 &
\end{tabular}

B

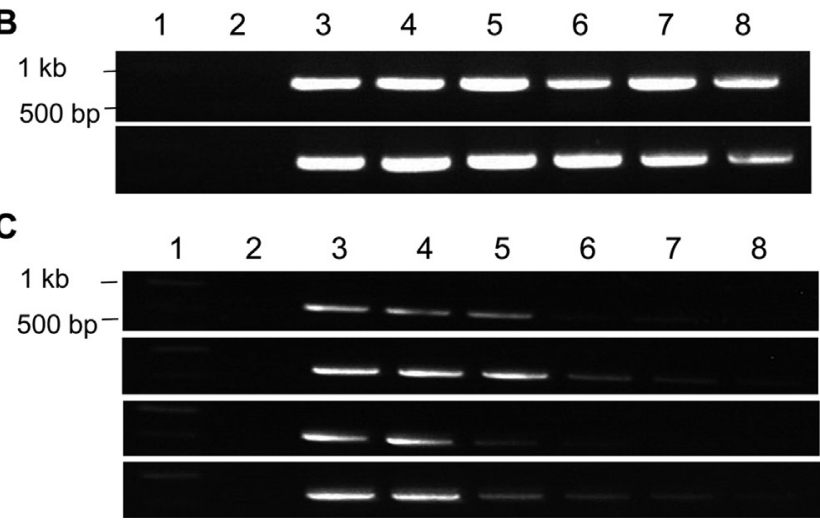

show apparent amplification at $0.1 \mathrm{ng}$ of templated DNA (2 $\left.\times 10^{-3} \mathrm{ng} / \mu \mathrm{l}\right)$. However, primer pairs Rt-4 and Rt-5 showed less sensitivity to detect $R t$ at the equivalent amount of template DNA (Fig. 4C). Sensitivity of the primer pairs was further investigated by qPCR with ten-fold diluted DNA of target bacteria. The tested two primer pairs for each bacterium showed similar sensitivity against target bacteria (data not shown).

Overall, our specificity and sensitivity assay with candidate primer pairs generated from comparative genome analysis revealed that most of primers were specific to amplify the target gene from the corresponding pathogenic bacteria, suggesting the gene probing from genome-based analysis is a promising tool to provide pathogen specific markers. However, the sensitivity of primers to detect target pathogen varied, which will need additional work to select best primer pairs. It will be more complicated if we consider plant component and plant genome to detect bacterial pathogen resided inside of plant seeds.
Fig. 4. Primer sensitivity assay using serially diluted genomic DNA of plant pathogenic bacteria. (A) Sensitive detection of Clavibacter michiganensis subsp. nebraskensis (Cmn), (B) sensitive detection of Pantoea stewartii subsp. stewartii (Pss), (C) sensitive detection of Rathayibacter tritici (Rt). Primer pairs and used bacterial strains of were indicated. Lane 1: DNA size standard; lane 2, no genomic DNA; lane 3, genomic DNA $150 \mathrm{ng}$; lane 4, genomic DNA $100 \mathrm{ng}$; lane 5, genomic DNA $50 \mathrm{ng}$; lane 6, genomic DNA 10 ng; lane 7, genomic DNA $1 \mathrm{ng}$; lane 8, genomic DNA $0.1 \mathrm{ng}$.

Detection of bacterial pathogens in artificially inoculated seeds. To test if the primer pairs developed in this study could be used to detect the target pathogen from seeds of corn and wheat effectively, we used seeds artificially inoculated with target bacteria. This is because all the three pathogens have not been reported in Korea, and seeds infected with Cmn, Pss, and $R t$ were not available. Among the primer pairs tested, three primer pairs, Rt-4, Cmn-3 and Pss2-4, exhibited the specific detection of bacteria from the artificially inoculated seeds (Fig. 5). The number of target bacteria on the corn seeds was enumerated for $\mathrm{Cmn}$ as $8.8 \times 10^{3} \mathrm{cfu} / \mathrm{g}$ seed, for Pss as $7.7 \times 10^{4} \mathrm{cfu} / \mathrm{g}$ seed, and for $R t$ on wheat seeds as $7.84 \times 10^{4} \mathrm{cfu} / \mathrm{g}$ seed. These results indicated that the selected primer pairs can detect target bacterial pathogens that are inhabited on the surface of seeds at the level of $10^{3}$ to $10^{4}$ cells per gram of seeds. No amplification of specific bacteria was detected from the sterilized seeds without bacterial inoculation or seeds not surface sterilized (Fig. 5). The seeds were randomly pur-

A

B

C

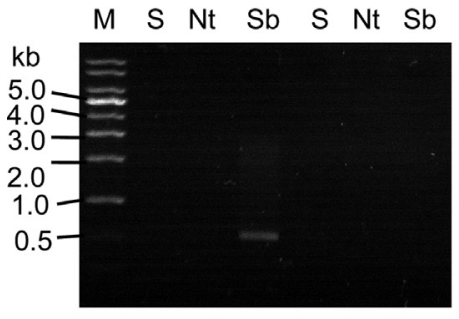

Rt-4
Rt-5

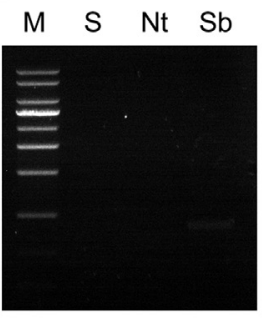

Cmn-3

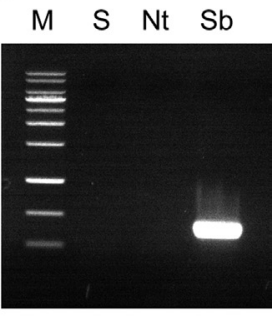

Pss2-4
Fig. 5. Specific detection of bacteria from the artificially inoculated seeds. (A) Detection of Rathayibacter tritici by Rt-4 on wheat seeds, (B) detection of Clavibacter michiganensis subsp. nebraskensis by $\mathrm{Cmn}-3$ on corn seeds, (C) detection of Pantoea stewartii subsp. stewartii by Pss2-3 on corn seeds. Lane M, DNA size standard (1 kb ladder); $\mathrm{S}$, seeds original; $\mathrm{Nt}$, surface sterilized seeds; $\mathrm{Sb}$, seeds infected with bacteria. 
chased from market and it turned out they might be target pathogen free.

Although we inoculated seeds of corn or wheat with either Cmn, Pss, or Rt, this is not natural assay because when bacteria infest the seeds in natural disease occurrence, the seeds may be both internally and externally contaminated (Rane and Latin 1992; Tancos et al., 2013). This assay was primarily performed using bacterial cells harvested from the surface but not from the total DNA isolated from grinded seeds. If infested seeds harbour pathogenic bacteria mostly inside the seeds, we require total DNA from the grinded seeds as a template, which will interfere with the specificity and sensitivity of primers. This should further be extensively tested with the naturally infected seeds, which was not possible to do in this study because of strict regulations to handle target bacterial pathogen in Korea.

\section{Acknowledgments}

This research was carried out with support by a grant from the Next Generation BioGreen21 (Project No. PJ01313101). Rural Development Administration, and by a grant from the Research of Animal and Plant Quarantine Agency, South Korea.

\section{References}

Agarkova, I. V., Lambrecht, P. A. and Vidaver, A. K. 2011. Genetic diversity and population structure of Clavibacter michiganesis subsp. nebraskensis. Can. J. Microbiol. 57:366-374.

Ahmed, N., Dobrindt, U., Hacker, J. and Hasnain, S. E. 2008. Genomic fluidity and pathogenic bacteria: applications in diagnostics, epidemiology and intervention. Nat. Rev. Microbiol. 6:387-394.

An, J. H., Noh, Y.-H., Kim, Y.-E., Lee, H.-I. and Cha, J.-S. 2015. Development of PCR and TaqMan PCR assays to detect Pseudomonas coronafaciens, a causal agent of halo blight of oats. Plant Pathol. J. 31:25-32.

Baker, G. C., Smith, J. J. and Cowan, D. A. 2003. Review and reanalysis of domain-specific $16 \mathrm{~S}$ primers. J. Microbiol. Methods 55:541-555.

Castillo, J. A. and Plata, G. 2016. The expansion of brown rot disease throughout Bolivia: possible role of climate change. Can. J. Microbiol. 62:442-448.

Cho, M. S., Kang, M. J., Kim, C. K., Seol, Y., Hahn, J. H., Park, S. C., Hwang, D. J., Ahn, T., Park, D. H., Lim, C. K. and Park, D. S. 2011. Sensitive and specific detection of Xanthomonas oryzae pv. oryzae by real-time bio-PCR using pathovar-specific primers based on an rhs family gene. Plant Dis. 95:589-594.

Coplin, D. L., Majerczak, D. R., Zhang, Y. X., Kim, W. S., Jock, S. and Geider, K. 2002. Identification of Pantoea stewartii subsp. Stewartii by PCR and strain differentiation by PFGE.
Plant Dis. 86:304-311.

De Boer, S., Wieczorek, A. and Kummer, A. 1988. An ELISA test for bacterial ring rot of potato with a new monoclonal antibody. Plant Dis. 72:874-878.

Demkin, V. V., Koshechkin, S. I. and Slesarev, A. 2017. A novel real-time PCR assay for highly specific detection and quantification of vaginal lactobacilli. Mol. Cell. Probes 32:33-39.

Eggenberger, S., Diaz-Arias, M. M., Gougherty, A. V., Nutter, F. W., Jr., Sernett, J. and Robertson, A. E. 2016. Dissemination of Goss's wilt of corn and epiphytic Clavibacter michiganesis subsp. nebraskensis from inoculum point sources. Plant Dis. 100:686-695.

Gudmestad, N. C., Mallik, I., Pasche, J. S., Anderson, N. R. and Kinzer, K. 2009. A real-time PCR assay for the detection of Clavibacter michiganensis subsp. sepedonicus based on the cellulase A gene sequence. Plant Dis. 93:649-659.

Hayward, A. C. 1964. Characteristics of Pseudomonas solanacearum. J. Appl. Bacteriol. 27:265-277.

Henriques, A., Cereija, T., Machado, A. and Cerca, N. 2012. In silico vs in vitro analysis of primer specificity for the detection of Gardnerella vaginalis, Atopobium vaginae and Lactobacillus spp. BMC Res. Notes 5:637.

Kang, I. J., Kang, M.-H., Noh, T.-H., Shim, H.-K., Shin, D. B. and Heu, S. 2016. Simultaneous detection of three bacterial seed-borne diseases in rice using multiplex polymerase chain reaction. Plant Pathol. J. 32:575-579.

Lamka, G. L., Hill, J. H., Mcgee, D. C. and Braun, E. J. 1991. Development of an immunosorbent-assay for seed-borne $\mathrm{Er}$ winia stewartii in corn seeds. Phytopathology 81:839-846.

Lee, J., Park, J., Kim, S., Park, I. and Seo, Y. S. 2016. Differential regulation of toxoflavin production and its role in the enhanced virulence of Burkholderia gladioli. Mol. Plant. Pathol. 17:65-75.

Mergaert, J., Verdonck, L. and Kersters, K. 1993. Transfer of Erwinia ananas (synonym, Erwinia uredovora) and Erwinia stewartii to the genus Pantoea emend. as Pantoea ananas (Serrano 1928) comb. nov. and Pantoea stewartii (Smith 1898) comb. nov., respectively, and description of Pantoea stewartii subsp. indologenes subsp. nov. Int. J. Syst. Evol. Microbiol. 43:162-173.

Michener, P. M., Pataky, J. K. and White, D. G. 2002. Rate of transmitting Erwinia stewartii from seed to seedlings of a sweet corn hybrid susceptible to Stewart's wilt. Plant Dis. 86:1031-1035.

Murray, T. D., Schroeder, B. K., Schneider, W. L., Luster, D. G., Sechler, A., Rogers, E. E. and Subbotin, S. A. 2017. Rathayibacter toxicus, other Rathayibacter species inducing bacterial head blight of grasses, and the potential for livestock poisonings. Phytopathology 107:804-815.

Nutter, F. W., Jr. and Madden, L. V. 2009. Plant pathogens as biological weapons against agriculture. In: Beyond anthrax: the weaponization of infectious disease, eds. by L. I. Lutwick and S. M. Lutwick, pp. 335-363. Springer, New York, USA.

Oh, E.-J., Bae, C., Lee, H.-B., Hwang, I. S., Lee, H. I., Yea, M. C., 
Yim, K.-O., Lee, S., Heu, S., Cha, J.-S. and Oh, C.-S. 2016. Clavibacter michiganensis subsp. capsici subsp. nov., causing bacterial canker disease in pepper. Int. J. Syst. Evol. Microbiol. 66:4065-4070.

Papaiakovou, M., Pilotte, N., Grant, J. R., Traub, R. J., Llewellyn, S., McCarthy, J. S., Krolewiecki, A. J., Cimino, R., Mejia, R. and Williams, S. A. 2017. A novel, species-specific, real-time PCR assay for the detection of the emerging zoonotic parasite Ancylostoma ceylanicum in human stool. PLoS Negl. Trop. Dis. 11:e0005734.

Park, J., Lee, P. A., Lee, H.-H., Choi, K., Lee, S.-W. and Seo, Y.-S. 2017. Comparative genome analysis of Rathayibacter tritici NCPPB 1953 with Rathayibacter toxicus strains can facilitate studies on mechanisms of nematode association and host infection. Plant Pathol. J. 33:370-381.

Paruthi, I. J. and Bhatti, D. S. 1985. Estimation of loss in yield and incidence of Anguina tritici on wheat in Haryana (India). Int. Nematol. Network Newsl. 2:13-16.

Paruthi, I. J. and Gupta, D. C. 1987. Incidence of 'tundu' in barley and kanki in wheat field infested with Anguina tritici. Haryana Agric. Univ. J. Res. 17:78-79.

Pataky, J. and Ikin, R. 2003. Pest risk analysis: the risk of introducing Erwinia stewartii in maize seeds. The International Seed Federation, Nyon.

Harwood, T. D., Moslonka-Lefebvre, M. and Pellis, L. 2010. Disease spread in small-size directed trade networks: the role of hierarchical categories. J. Appl. Ecol. 47:1300-1309.

Rane, K. K. and Latin, R. X. 1992. Bacterial fruit blotch of watermelon: association of the pathogen with seed. Plant. Dis. 76:509-512.

Rozen, S. and Skaletsky, H. 2000. Primer3 on the WWW for general users and for biologist programmers. Methods Mol. Biol. 132:365-386.

Smidt, M. and Vidaver, A. K. 1986. Population dynamics of Clavibacter michiganesis subsp. nebraskensis in field-grown dent corn and popcorn. Plant Dis. 70:1031-1036.

Tambong, J. T., Mwange, K. N., Bergeron, M., Ding, T., Mandy, F., Reid, M. and Zhu, X. 2008. Rapid detection and identification of the bacterium Pantoea stewartii in maize by TaqMan real-time PCR assay targeting the cpsD gene. J. Appl. Microbiol. 104:1525-1537.
Tancos, M. A., Chalupowicz, L., Barash, I., Manulis-Sasson, S. and Smart, C. D. 2013. Tomato fruit and seed colonization by Clavibacter michiganensis subsp. michiganensis through external and internal routes. Appl. Environ. Microbiol. 79:69486957.

Tao, T., Chen, Q., Bie, X., Lu, F. and Lu, Z. 2015. Mining of novel species-specific primers for PCR detection of Listeria monocytogenes based on genomic approach. World J. Microbiol. Biotechnol. 31:1955-1966.

Vidaver, A. K. 1967. Synthetic and complex media for the rapid detection of fluorescence of phytopathogenic Pseudomonas: effect of carbon source. Appl. Microbiol. 15:1523-1524.

Vidaver, A. K. and Mandel, M. 1974. Corynebacterium nebraskense a new, orange-pigmented phytopathogenic species. Int. J. Syst. Bacteriol. 24:482-485.

Vincelli, P. and Tisserat, N. 2008. Nucleic acid-based pathogen detection in applied plant pathology. Plant Dis. 92:660-669.

Wensing, G. A., Gernold, M., Wiedermann, W., Coplin, D. L. and Geider, K. 2014. Molecular differentiation of Pantoea stewartii subsp. indologenes from subspeces stewartii and identification of new isolates from maize seeds. J. Appl. Microbiol. 116:1553-1562.

Wensing, A., Zimmermann, S. and Geider, K. 2010. Identification of the corn pathogen Pantoea stewartii by mass spectrometry of whole-cell extracts and its detection with novel PCR primers. Appl. Environ. Microbiol. 76:6248-6256.

Yim, K.-O., Lee, H.-I., Kim, J.-H., Lee, S.-D., Cho, J.-H. and Cha, J.-S. 2012. Characterization of phenotypic variants of Clavibacter michiganensis subsp. michiganensis isolated from Capsicum annuum. Eur. J. Plant Pathol. 133:559-575.

Yu, S., Chen, W., Wang, D., He, X., Zhu, X. and Shi, X. 2010. Species-specific PCR detection of the food-borne pathogen Vibrio parahaemolyticus using the $\operatorname{irg} B$ gene identified by comparative genomic analysis. FEMS Microbiol. Lett. 307:65-71.

Zgurskaya, H. I., Evtushenko, L. I., Akimov, V. N. and Kalakoutskii, L. V. 1993. Rathayibacter gen. nov., including the species Rathayibacter rathayi comb. nov., Rathayibacter tritici comb. nov., Rathayibacter iranicus comb. nov., and six strains from annual grasses. Int. J. Syst. Bacteriol. 43:143149. 